\title{
Impact of Abuse Potential of Alcoholic and Non- alcoholic Fathers on Adjustment Pattern of Rural Adolescents
}

\author{
Chetna Mahajan ${ }^{1 *}$, Sukhminder Kaur ${ }^{2}$
}

\section{ABSTRACT}

The study was conducted on a sample of 120 adolescents with alcoholic and non- alcoholic fathers drawn equally from six rural locations in Ludhiana district. Data were collected using a Personal Information Sheet, a self- structured Interview Schedule and an Adjustment Inventory. The alcoholic fathers were perceived to be as having high abuse potential by the adolescents; however majority of the girls (73.33\%) experienced low abuse compared to boys. Beating was the most predominantly used type of punishment by the fathers. Adolescents of non- alcoholic fathers showed better adjustment in different areas viz home, school, social and health adjustment.

Keywords: Adolescents, Adjustment, Alcoholic, Fathers, Rural

The problem of alcoholism has posed a serious threat to modern civilization. In India, about 15 to 20 per cent of people consume alcohol and over the past 20 years, the number of alcoholics in India has increased from one in 300 to one in 20 (Smentha, 2006). The World Health Organization estimates that about 140 million people throughout the world suffer from alcohol dependence (Smentha, 2006). A wide variation in estimates of prevalence of alcoholics in India has been reported as 16.7 per cent in Madras city to 49.6 per cent in Punjab villages. It has been estimated that 6.6 million children under the age of 18 years live in the households with at least one alcoholic parent and are at risk for a range of emotional, cognitive and behavioural problems (World Health Organization, 2004). The psychological, social, physiological, familial and occupational disturbances also arise due to adverse consequences of alcoholism (Mohanty, 2001). An 'alcoholic' is defined as one whose drinking interferes frequently or continuously with any of his important life adjustments and interpersonal relationships (Clinebell, 1983).

\footnotetext{
${ }^{1}$ Research Scholar, Department of Human Development, College of Home Science, Punjab Agricultural University, Ludhiana, India

${ }^{2}$ Senior Extension Specialist, Department of Human Development, College of Home Science, Punjab Agricultural University, Ludhiana, India

*Responding Author

(C) 2016, C Mahajan, S Kaur; licensee IJIP. This is an Open Access Research distributed under the terms of the Creative Commons Attribution License (http://creativecommons.org/licenses/by/2.0), which permits unrestricted use, distribution, and reproduction in any Medium, provided the original work is properly cited.
} 
Literature also reveals that alcohol is the cause of substantial number of domestic violence accidents and has been significant risk factor for husband to wife violence (Gmel and Rehm, 2003). Recognizing violence in alcoholic families as a fundamental abuse, United Nations (2002) defined such violence as encompassing but not limited to physical, sexual and psychological violence occurring in the family including battering, sexual abuse of female children in the household, dowry related violence, marital rape, female genital mutilation and other traditional practices harmful to family, non-spousal violence and violence related to exploitation. Child abuse is perhaps the most visible form of family violence. Frequently, infants, children and adolescents are burned, bruised, beaten, starved, suffocated, sexually abused or otherwise mistreated by their parents/caretakers. They are not only targets of physical violence but are victims of psychological maltreatment too, that is they are rejected, verbally abused and even terrorized by their parents (Hart and Brassard, 1987).

Child abuse can also be defined as "causing or permitting any harmful or offensive contact on a child's body and any kind of communication or transaction of speech which humiliates, shames, or frightens the child." It can also be defined as any act or omission, which fails to nurture or in the upbringing of the children (World Health Organization, 2004). In the Indian context the definition of child abuse was evolved by a committee in a National Seminar held at National Institute of Public Cooperation and Child Development, New Delhi (1988) as "The intentional, non-accidental injury, maltreatment of children by parents, caretakers, employers or others including those individuals representing governmental or non-governmental bodies which may lead to temporary or permanent impairment of their physical, mental and psychological development, disability or death”(NIPCCD, 1988 ).

The alcohol abuse in rural communities is particularly a serious problem and more so in the poor socio- economic strata, where a disproportionate amount of family income is spent on alcohol leaving very little money for food, education, housing and health (Smentha, 2006). Besides this, illogical arguments and conflicting situations between partners due to alcoholism have a profound effect on the development of children; they are robbed of attention, consistent discipline and trust worthy environment. The major effects are shown on adolescents since they are passing through the most sensitive phase of development. Adolescents living with an alcoholic parent have been reported to experience more delinquency problems (Obot and Antony, 2004) and long lasting damage in psychological, physiological and social domains. Children in such families are likely to have a history of physical or sexual assault, abuse and domestic violence than those in general population which can lead to depression, anxiety, panic and personality disorders (Rockville, 2002). Moreover, these children exhibit more symptoms of generalized stress, low self esteem, a feeling of lack of control over their environment, loneliness, guilt, feelings of helplessness, fears of abandonment, chronic depression and an increased risk of developing mental health 
problems (Anderson and Quast, 1983; Morey, 1991; Sher et al., 1991; Cuuijpers et al., 2006). Adolescent children of alcoholics have been reported to be significantly lower on all psychological factors of at risk temperament, feelings, thoughts and behaviour, emotional and social distress, anxiety disorders and frequent occurrence of post traumatic stress disorder, poor intellectual functioning, deficits in verbal abilities and poor academic performance than children of non-alcoholics. These children are also at risk of depression, suicide, eating disorder and chemical dependency (Berger, 1993; Mylant, et al., 2002; Sebre et al., 2004; Vungkhanching et al., 2004) and often experience high levels of tension and stress.

The problem of alcoholism has been explored from several perspectives such as etiological, socio-cultural, psycho-dynamic, interpersonal, biological, therapeutic intervention and outcome etc. While most researchers have focused attention on the behaviour of alcoholics, communication, personality, drinking pattern and so on, the realization is that it is the family who bears the brunt of the father's alcoholism and may develop parallel emotional and behavioural problems (Joseph, 2003). Hence it is imperative to undertake such research studies which will reveal the impact of alcoholism on developmental pattern of children in the family especially the adolescents who are passing through a most sensitive stage of human life. Moreover the abuse potential among alcoholic and non-alcoholic fathers and its impact on adjustment pattern of adolescents that too in rural areas has not received requisite attention of scientists/researchers and consequently scant literature on this aspect is available. Hence, the present study was undertaken with the objectives 1) to determine the prevalence of abuse potential among alcoholic and non-alcoholic fathers 2) to determine the type of punishment experienced by the adolescents and 3) to assess the impact of abuse potential of alcoholic and non-alcoholic fathers on adjustment pattern of rural adolescents.

\section{METHOD}

\section{Study Location:}

Rural locations of Punjab state in India.

\section{Study Design:}

Cross-sectional exploratory study.

\section{Sample size:}

The sample comprised of 120 adolescents (11-16years) with alcoholic and non- alcoholic fathers. A total of 60 families with alcoholic fathers and 60 families with non-alcoholic fathers having adolescents (both boys and girls) were selected.

\section{Inclusion criteria:}

a) families of alcoholic (daily/frequent drinkers) and non-alcoholic fathers having adolescent children in the age group of $11-16$ years

(b) both boys and girls (30 each), pertaining to alcoholic and non- alcoholic fathers. 


\section{Procedure}

The study aimed at documentation of abuse potential among alcoholic and non- alcoholic fathers of the adolescents selected from six rural locations in one block of Ludhiana district of Punjab state using simple random sampling technique. Each selected village was visited to identify the families of alcoholic (daily/frequent drinkers) and non-alcoholic fathers having adolescent children in the age group of 11 - 16 years by contacting the village leader (Sarpanch) of the village. A total of 60 families (10 from each village) with alcoholic fathers having adolescents (both boys and girls) in the required age group were identified. Similarly 60 families with nonalcoholic fathers and having adolescents (both boys and girls) fulfilling the age criterion were randomly selected from all the villages. Thus the total sample comprised of 120 adolescents, both boys and girls (30 each), pertaining to alcoholic and non- alcoholic fathers.

\section{Tools}

Personal Information Sheet (PIS): The PIS recorded the background profile of the adolescents such as age, gender, family type, family size, number of siblings, education and occupation of parents and monthly income of the family.

Interview Schedule (IS) relating to Abuse Potential: The IS contained information on various queries such as nature of father, interaction of adolescents with their father, conflicting situations between adolescents and their fathers, level of alcohol consumption by the father, father's behaviour towards adolescents in an inebriated condition, practices inflicted by fathers to punish the adolescents such as scolding, shouting, pushing, verbally abusing, beating etc.

After constructing the interview schedule it was circulated among the experts of Human Development, Extension Education and Sociology and then modified in the light of suggestions given by them. The IS was pre-tested and test-retest reliability was calculated to be 0.89 using Karl Pearson's correlation co-efficient. The level of low and high abuse potential among fathers of the adolescents was calculated on the basis of mean \pm SD ( Mean \pm Standard Deviation) of the scores obtained by them.

Adjustment Inventory: The adjustment inventory developed by Mittal (1974) was used to assess the adjustment pattern of the adolescents experiencing abuse by both alcoholic and nonalcoholic fathers. The inventory is intended for use with students ranging in age from eleven years to adulthood including both genders. This scale consists of four different areas of adjustment viz home adjustment, social adjustment, health adjustment and school adjustment. In all there are 80 items which are equally distributed amongst the above mentioned four areas of adjustment. Each item is recorded in three different response categories that is (i) Yes, (ii) ? and (iii) No and is also scaled separately for male and female adolescents from excellent adjustment to very unsatisfactory adjustment and the score range for different categories varies [excellent adjustment (M- 220+ and F- 219+), good adjustment (M- 200-200 and F- 207-219), 
satisfactory adjustment(M- 160-200 and F-183-207), unsatisfactory adjustment(M- 140-160 and F- 171-183) and very unsatisfactory adjustment (M- <120-140 and F- <159-171)]. Scoring was done by using scoring key. Maximum possible score which can be obtained by the respondent is 240 and minimum possible score is 80 . Total scores obtained in all the different categories shows overall adjustment score.

\section{Data Collection and Analysis}

Data were collected in the households of adolescents having both alcoholic and non-alcoholic fathers developing close rapport with the adolescents. In the first phase, information relating to the demographic profile and abuse potential of alcoholic and non-alcoholic fathers was collected by personally interviewing all the selected adolescents. After that the adolescents experiencing abuse by their alcoholic and non-alcoholic fathers were identified by calculating mean \pm standard deviation $(\bar{X} \pm \mathrm{SD}$ ) of the scores obtained by them. In the second phase, the adjustment inventory was applied to the selected adolescents to determine their adjustment pattern. Data were analysed using frequencies, percentages, means, standard deviation, t-test and chi-square test.

\section{RESULTS AND DISCUSSION}

\section{Background profile of the adolescents}

The respondents were equally distributed between families with alcoholic and non-alcoholic fathers (60 each) with 50 per cent adolescent boys $(n=30)$ and adolescent girls $(n=30)$ in each category (Table1). More than forty per cent (41.67\%) of the adolescents were in the age group of 11-14 years whereas 58.33 per cent of them were 14-16 years old. Adolescents (53.33\%) were having two siblings whereas 46.67 per cent of them had three siblings. Majority of the fathers of the adolescents (63.33\%) were educated upto matric whereas majority of the mothers (62.50\%) were found to be illiterate (Table1). More than fifty per cent fathers (51.67 \%) of the adolescents were involved into business, 42.50 per cent were laborers and only 5.83 per cent were engaged in service. On the other hand, a higher percentage of the mothers (66.67 \%) were non-working and rest of them were engaged as domestic servants. Majority of the adolescents (71.67\%) belonged to joint families and most of the adolescents of alcoholic families (58.33 \%) and non-alcoholic families $(53.33 \%)$ had ten to twelve and even more family members. The monthly income of families of adolescents from all sources ranged from Rs. 7000/- to Rs 11000/-.

\section{Prevalence of abuse potential among alcoholic and non-alcoholic fathers}

Data pertaining to prevalence of abuse potential among alcoholic and non-alcoholic fathers is presented in Table 2. The mean of the scores obtained by the adolescents was calculated to be 17.0 and the standard deviation was 7.9. Therefore, the adolescents having alcoholic fathers (20.00\%) and adolescents having non-alcoholic fathers (8.33\%) obtaining less than nine $(<9.1)$ scores were not considered to be abused by their fathers and hence they were dropped (Fig.1). Further, 
56.67 per cent adolescents having alcoholic fathers and 80.00 per cent adolescents having nonalcoholic fathers scoring between (9.1-17.0) were considered to be experiencing low abuse whereas 23.33 per cent adolescents having alcoholic fathers and 11.67 per cent adolescents having non-alcoholic fathers were categorized as high on abuse (score range 17.1-24.9 and above). Statistically also significant association was found between the alcoholism and abuse potential among fathers (Table 2 ) since the chi-square was calculated to be significant $(\chi 2$ - value $=4.27 ; \mathrm{P}<0.05)$.

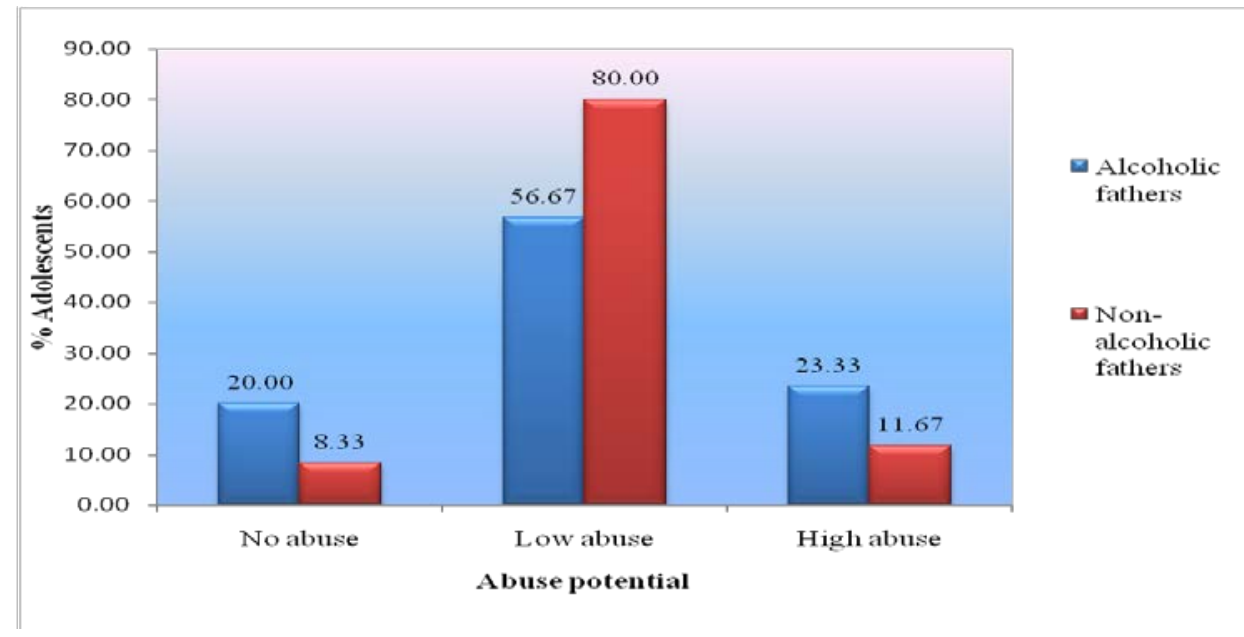

Fig. 1: Abuse potential among alcoholic and non-alcoholic fathers towards their adolescent children

The study revealed significant association between the alcoholism and abuse potential among fathers. Reich et al (1993) also reported that children of alcoholics experienced high rates of abuse potential compared to non-alcoholics. Dave et al (1982) reported that the spectrum of child abuse and neglect was observed to be practiced at individual, social and institutional levels and occurred in the form of isolated incident or chronic or repeated episodes of abuse. West and Prinz (1987) reviewed the studies done on parental alcoholism and childhood psychopathology and reported that the literature as a whole supported the contention that parental alcoholism and abuse is associated with a heightened incidence of child symptoms of child psychopathology.

\section{Gender wise distribution of adolescents with reference to abuse potential among alcoholic and non-alcoholic fathers}

It was found that overall 11.67 per cent girls and 16.67 per cent boys experienced no abuse by their fathers, whereas girls (73.33 \%) and boys (63.33\%) experienced low abuse and more boys (20.00 \%) as compared to girls (15.00 \%) were highly abused (Fig.2). Alcoholic fathers were found to be more abusive since they scored high and they were found to be more abusive towards boys. These finding of the present study are corroborated by the findings of Creighton (2002) which revealed that among 8000 teenage children in the physical abuse category in England, more boys registered for physical abuse compared to girls in both alcoholic and nonalcoholic families. 


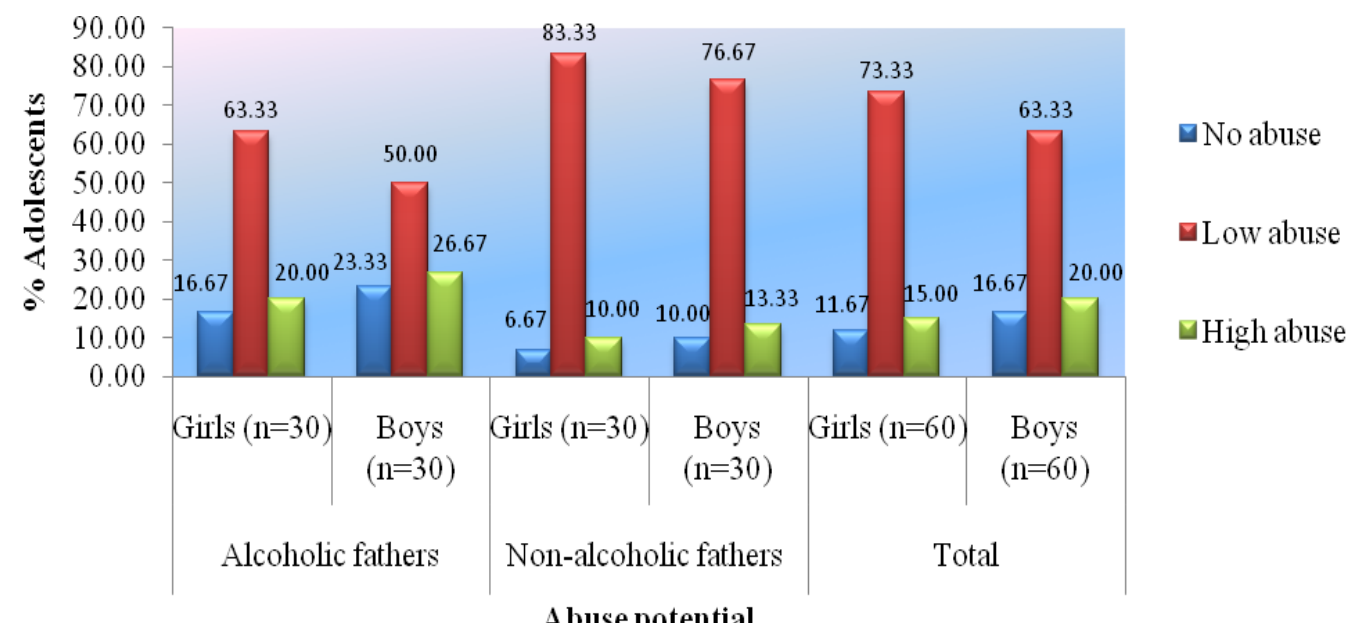

Fig. 2: Gender differences among adolescents as per abuse potential of alcoholic and nonalcoholic fathers

\section{Type of punishment experienced by the adolescents}

Adolescents experienced various types of punishment by their alcoholic and non-alcoholic fathers viz scolding and shouting, twisting and pinching of ears/arms, threatening with weapon and beating. Alcoholic fathers were found to have high abuse potential compared to nonalcoholic fathers since they scored high on all the four types of punishment inflicted by them on their adolescent children (Table 3). Statistically also there were highly significant differences among them in use of type of punishment viz scolding/shouting ( $\mathrm{t}$-value $=10.50$; $\mathrm{P}$ $<0.01$ ), twisting and pinching ears/arms (t-value $=12.12$; $\mathrm{P}<0.01$ ), threatening with weapon $(\mathrm{t}$-value $=14.19 ; \mathrm{P}<0.01)$ and beating the adolescents $(\mathrm{t}$-value $=12.66 ; \mathrm{P}<0.01)$. Results further revealed highly significant differences in the type of punishment used by the alcoholic fathers (F-ratio = 11.78; $\mathrm{P}<0.01$ ) and non-alcoholic fathers (F-ratio $=9.43 ; \mathrm{P}<0.01)$. Beating was the most predominantly used type of punishment by both alcoholic (mean score $=33.54$ ) and nonalcoholic fathers (mean score $=21.34$ ), followed by threatening with weapon, twisting and pinching ears/arms. Scolding/ shouting was the minimally used type of punishment by both alcoholic (mean score $=18.24$ ) and non-alcoholic fathers (mean score $=12.28)$. Even low abuse adolescents mostly experienced beating by their alcoholic (mean score $=32.87$ ) and non-alcoholic fathers (mean score $=20.97$ ) followed by the other types of punishment. Similarly in case of high abuse category mostly beating was used by the alcoholic (mean score $=35.17$ ) and non- alcoholic fathers (mean score $=23.88$ ) followed by other practices. Alcoholic fathers were found to have high scores on each type of punishment. Beating was most predominantly used type of punishment by both alcoholic and non-alcoholic fathers. Even in case of low abuse category adolescents mostly experienced beating. This may be attributed to the fact that most of the parents use beating as a disciplinary technique for behavior modification of their children. Gelles (1979) also investigated that majority of parents (73\%) of children in their teenage, admitted some form of 
aggression towards them, including spanking and slapping; approximately 4.0 per cent admitted kicking, beating or hitting the child with a fist and 3.0 per cent admitted threatening with gun or knife against the child at some time. Fathers were more likely than mothers to spank and hit their children particularly son and were engaged in more severe violent actions or to use weapons. Daughters and sons were equally likely to be target of such serious attacks.

\section{Adjustment pattern of adolescents of alcoholic and non-alcoholic fathers}

It is evident from the table 4 that adolescents of non-alcoholic fathers showed better adjustment in all the areas viz home, school, social and health adjustment. Adolescents of non-alcoholic fathers scored high on home adjustment (mean score $=75.32$ ) compared to adolescents of alcoholic fathers (t-value $=2.76 ; \mathrm{P}<0.01)$. Again adolescents of non-alcoholic fathers had better adjustment at school ( $\mathrm{t}$-value $=2.97 ; \mathrm{P}<0.01)$, social adjustment $(\mathrm{t}$-value $=4.04 ; \mathrm{P}<0.01)$ and health adjustment (t-value $=2.48 ; \mathrm{P}<0.01)$ compared to adolescents of alcoholic fathers. The data further enlightens that adolescents of alcoholic fathers revealed maximum adjustment problems relating to health followed by school and social adjustment in case of both low as well as high abuse categories. However they were found to be better adjusted in the area of home adjustment. But the adolescents of non-alcoholic fathers scored high in both the low abuse (mean score $=76.10$ ) and high abuse categories (mean score $=72.46)$ in the area of home adjustment compared to adolescents of alcoholic fathers. Previous research by Stanley and Vanitha also (2008) analyzed lower self-esteem and poor adjustment in all domains among the adolescent children of alcoholics than the non-alcoholics. These deficits can be attributed to the increased stress and vitiated domestic environment due to alcoholism. Davis and Cummings (1994) evaluated that both poor parent-child and poor inter-parental relationships in alcoholic families can adversely affect children's emotional security which in turn makes interparental conflicts more threatening to their sense of family stability. Tweed (1991) also reported that children were influenced by their negative family environment and overall risk factors tended to be family conflict and negative parent-child relationships.

\section{Profile of overall adjustment pattern of adolescents}

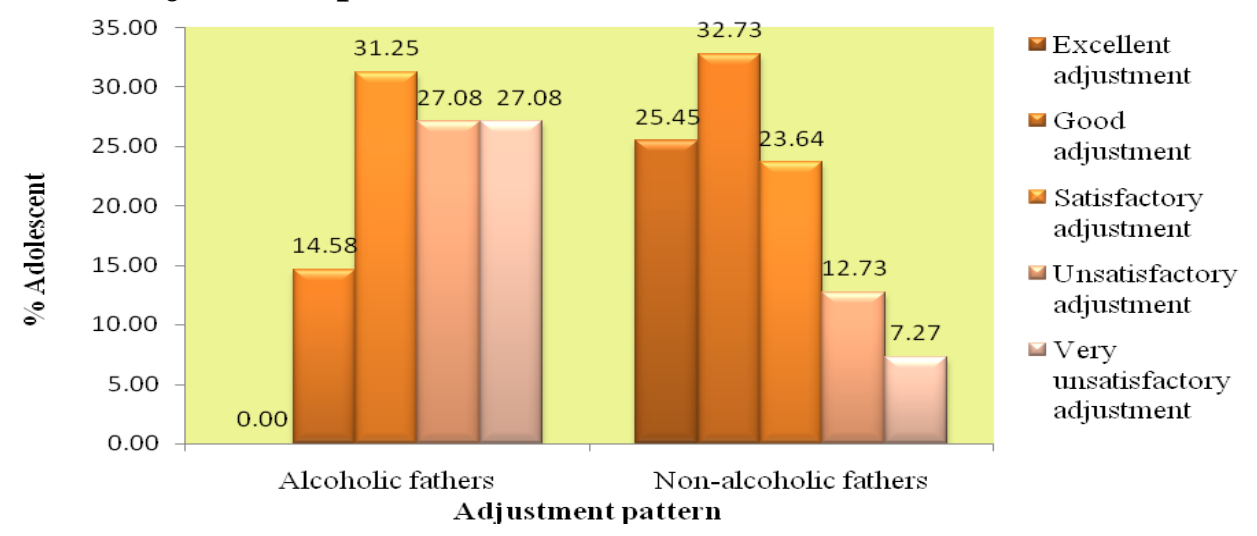

Fig 3: Adjustment pattern of the abused adolescents

(c) The International Journal of Indian Psychology, ISSN 2348-5396 (e)| ISSN: 2349-3429 (p) | 56 
The results revealed that more than thirty per cent (31.25\%) adolescents of alcoholic fathers reported satisfactory adjustment whereas 23.64 per cent of adolescents of non-alcoholic fathers showed satisfactory adjustment, more than twenty seven per cent (27.08) of adolescents of alcoholic fathers showed each unsatisfactory and very unsatisfactory adjustment whereas more than twenty five per cent (25.45 \%) adolescents of non-alcoholic fathers showed excellent adjustment followed by 32.73 per cent who showed good adjustment. However none of the adolescents with alcoholic fathers showed excellent adjustment. The adjustment pattern of 12.73 per cent adolescents with non- alcoholic fathers was unsatisfactory and only few adolescents (7.27 \%) were found to have very unsatisfactory adjustment (Fig.3). Earlier Hovland (1991) identified alcohol problem families as those in which the alcohol related behaviour of a member has caused repeated financial, legal, health or social consequences. Significant interactions were found between drinking behaviour of subjects, their perception of family functioning, family alcohol abuse and personality variables, resulting into less adjustment pattern shown by the offspring. Storm (2003) examined possible risk factors associated with child adjustment in a sample of children with alcohol abusing fathers. Children of alcohol abusing fathers were found to have more adjustment problems as compared to children of non-alcoholic fathers, the factors such as parental alcohol abuse (severity of alcohol abuse, the child's level of exposure to the alcohol abuse, changes in routine and rituals due to abuse potential of fathers were found to be related to adjustment pattern of their adolescent children.

Thus it is apparent from the above discussion that alcoholic nature of fathers does have negative impact on the adjustment pattern of the adolescents, hence there is a dire need to plan and organize intervention programmes for counselling of alcoholic fathers wherein lectures or talks can be arranged by experts to create awareness among rural folk on the ill-effects of alcoholism on health, family relations and personality development of children. Religious functions in the villages can be the most appropriate platform for this purpose. Mass media like radio, television, newspapers etc. may highlight the impact of abuse potential among alcoholic and non-alcoholic fathers on children/adolescents by publishing relevant literature and guidelines from time to time.

\section{Acknowledgments}

The author appreciates all those who participated in the study and helped to facilitate the research process.

\section{Conflict of Interests}

The author declared no conflict of interests. 


\section{LITERATURE CITED}

Anderson E and Quast W (1983). Young children in alcoholic families: a mental health drinking needs assessment intervention/prevention strategy. J of Primary Prevention; 31: 174-187.

Berger G (1993). Alcoholism and the family. Pp. 13-90. Franklin Watts, New York.

Clinebell M (1983). Study on alcoholism and alcoholics behaviour. Pp. 362. (Original not seen. Cited by Mohanty G, 2004 Text book of Abnormal Psychology. Kalyani Publishers, Ludhiana).

Creighton R (2002). Children of Alcoholics. Horizons Psychology; 11: 95-107.

Cuijpers P, Steunenberg B and Van Straten A (2006). When children of problem drinkers grow old: does the increase risk of mental disorders persist? Addictive Behaviour; 31: 22842291.

Dave A B, Dave P B and Mishra K D (1982). Child abuse and neglect (CAN) practices in Alcohol District of Madhya Pradesh. Indian Pediatrics; 19: 34-38.

Davis P T and Cummings E M (1994). Marital conflict and child adjustment: an emotional security hypothesis. Psychological Bulletin; 116: 387-411.

Gelles R J (1979). Violence towards children in the United States. Journal of American Academy of Child Adolescent Psychiatry; 95: 549-581.

Gmel G and Rehm J (2003). Harmful alcohol abuse. J of Alcoholic Research and Health; 42: 116-128.

Hart S N and Brassad M R (1987). A major threat to children's mental health, Psychological maltreatment. American Psychologist; 42: 160-165.

Hovland J C 1991. The interaction of personality, behavioural and family variables in offspring of alcohol problem families vs controls. Clinical Experiments in Research; 8, 330-333.

Joseph J (2003). Family relationships as viewed by parents and adolescents: a specification. Journal of Marriage and Family; 43: 95-107.

Mittal V K (1974). Adjustment Inventory. Pp. 1-12.Manivigyan Kendra, Meerut.

Mohanty G (2001). A text book of Abnormal Psychology. Pp. 354-364. Kalyani Publishers, Ludhiana.

Morey C K (1999) Children of alcoholics: A comparative study. Journal of Drug Education; 29:63-75

Mylant M L, Ide B, Cuevas E and Meehan M (2002). Adolescent children of alcoholics: Vulnerable or resilient? Journal of American Psychology; 18: 57-64.

NIPCCD (1988). Child abuse in India. Report of a National Seminar. Pp. 1-120. National Institute of Public Cooperation and Child Development, New Delhi.

Obot I S and Antony J C (2004). Mental Health Problems in adolescent children of alcohol dependent parents: Epidemiologic research with a nationally representative sample. Journal of Child and Adolescent Substance Abuse; 13: 83-96.

Reich W, Earls F, Frankel O and Shayka J J (1993.) Psychopathology in children of alcoholics. Journal of American Academy of Child Adolescent Psychiatry; 32: 995-1002. 
Rockville M D (2002). Facts about Alcohol and Alcoholism. Pp. 1-12. National institute on alcohol abuse and alcoholism, Karnataka.

Sebre S, Sprugevica I, Novotni A, Bonevski D, Pakalniskiene V, Popescu D, Turchina T, Friedrich W and Lewis O (2004). Cross cultural comparisons of child-reported emotional and physical abuse: rates, risk factors and psychosocial symptoms. Child Abuse and Neglect; 28: 113-127.

Sher K J, Walitzer K S, Wood P K and Brent E E (1991). Characteristics of children of alcoholics: putative risk factors and psychopathology. Journal of Abnormal Psychology; 100: 427-448.

Smentha (2006). Alcoholism: a curse for families. The Hindustan Times, Febuary 9, Pp. 4.

Stanley S and Vanitha C (2008). Psychological correlates in adolescent children of alcoholics: Implications of intervention. International Journal of Psycho-social Rehabilitation; 12: 67-80.

Storm B H (2003). Parental alcohol abuse relationships between child adjustment, parental characteristics and family functioning. Child Psychology and Human Development; 32:127-146.

Tweed S H (1991). Factors influencing the psychological adjustment of adult children of alcoholics. Indian Journal of Psychology; 65: 27-36.

United Nations (2002). A review on effects of alcohol. Pp. 362. (Original not seen. Cited by Mohanty G, 2004 Text book of Abnormal Psychology. Kalyani Publishers, Ludhiana).

Vungkhanching M, Sher K J, Jackson K M and Parra G R (2004). Relation of attachment style to family history of alcoholism and alcohol use disorders in early adulthood. Drug Alcohol Dependence; 75:47-53.

West M O and Prinz R J (1987). Parental alcoholism and child psychopathology. Psychological Bulletin; 102: 204-218.

World Health Organization (2004). Global Status Report on Alcoholism. Pp. 1-94. Department of mental health and substance abuse, Geneva. 
Impact of Abuse Potential of Alcoholic and Non- alcoholic Fathers on Adjustment Pattern of Rural Adolescents

Table 1: Background profile of the adolescents $(n=120)$

\begin{tabular}{|c|c|c|c|}
\hline Variable & $\begin{array}{l}\text { Alcoholic Fathers } \\
\qquad(\mathrm{n}=60)\end{array}$ & $\begin{array}{l}\text { Non-Alcoholic Fathers } \\
(\mathbf{n}=60)\end{array}$ & Total $(n=120)$ \\
\hline $\begin{array}{l}\text { 1. Age Group (yrs) } \\
\text { a) } 11 \text { to } 14 \\
\text { b) } 14 \text { to } 16 \\
\end{array}$ & $\begin{array}{l}25(41.67) \\
35(58.33)\end{array}$ & $\begin{array}{l}25(41.67) \\
35(58.33)\end{array}$ & $\begin{array}{l}50(41.67) \\
70(58.33)\end{array}$ \\
\hline $\begin{array}{l}\text { 2. Gender } \\
\text { a) Male } \\
\text { b) Female } \\
\end{array}$ & $\begin{array}{l}30(50.00) \\
30(50.00)\end{array}$ & $\begin{array}{l}30(50.00) \\
30(50.00)\end{array}$ & $\begin{array}{l}60(100.00) \\
60(100.00)\end{array}$ \\
\hline $\begin{array}{l}\text { 3. No. of Siblings } \\
\text { a) Two } \\
\text { b) Three }\end{array}$ & $\begin{array}{l}31(51.67) \\
29(48.33)\end{array}$ & $\begin{array}{l}33(55.00) \\
27(45.00)\end{array}$ & $\begin{array}{l}64(53.33) \\
56(46.67)\end{array}$ \\
\hline $\begin{array}{l}\text { 4. Fathers education } \\
\text { a) Illiterate } \\
\text { b) Matric \& below }\end{array}$ & $\begin{array}{l}36(60.00) \\
24(40.00)\end{array}$ & $\begin{array}{l}8(13.33) \\
52(86.67)\end{array}$ & $\begin{array}{l}44(36.67) \\
76(63.33)\end{array}$ \\
\hline $\begin{array}{l}\text { 5. Mothers education } \\
\text { a) Illiterate } \\
\text { b) Matric \& below }\end{array}$ & $\begin{array}{l}45(75.00) \\
15(25.00)\end{array}$ & $\begin{array}{l}30(50.00) \\
30(50.00)\end{array}$ & $\begin{array}{l}75(62.50) \\
45(37.50)\end{array}$ \\
\hline $\begin{array}{l}\text { 6. Fathers occupation } \\
\text { a) Business } \\
\text { b) Labourer } \\
\text { c) Service } \\
\end{array}$ & $\begin{array}{c}34(56.67) \\
26(43.33) \\
0(0.00) \\
\end{array}$ & $\begin{array}{c}28(46.67) \\
25(41.67) \\
7(11.67) \\
\end{array}$ & $\begin{array}{c}62(51.67) \\
51(42.50) \\
7(5.83) \\
\end{array}$ \\
\hline $\begin{array}{l}\text { 7. Mothers occupation } \\
\text { a) Working } \\
\text { b) Non working }\end{array}$ & $\begin{array}{l}16(26.67) \\
44(73.33)\end{array}$ & $\begin{array}{l}24(40.00) \\
36(60.00)\end{array}$ & $\begin{array}{l}40(33.33) \\
80(66.67)\end{array}$ \\
\hline $\begin{array}{l}\text { 8. Family Type } \\
\text { a) Joint } \\
\text { b) Nuclear }\end{array}$ & $\begin{array}{l}44(73.33) \\
16(26.67)\end{array}$ & $\begin{array}{l}42(70.00) \\
18(30.00)\end{array}$ & $\begin{array}{l}86(71.67) \\
34(28.33)\end{array}$ \\
\hline $\begin{array}{l}\text { 9. Family size (No. of } \\
\text { family members) } \\
\text { a) }<7 \\
\text { b) } 7-10 \\
\text { c) } 10-12 \text { and above }\end{array}$ & $\begin{array}{l}15(25.00) \\
10(16.67) \\
35(58.33) \\
\end{array}$ & $\begin{array}{l}12(20.00) \\
16(26.67) \\
32(53.33) \\
\end{array}$ & $\begin{array}{l}27(22.50) \\
26(39.00) \\
67(55.83) \\
\end{array}$ \\
\hline $\begin{array}{l}\text { 10. Monthly Income of } \\
\text { the family } \\
\text { a) } 7000 \text { and below } \\
\text { b) } 7001-9000 \\
\text { c) } 9001-11000 \text { and } \\
\text { above }\end{array}$ & $\begin{array}{l}22(36.70) \\
19(31.70) \\
19(31.67)\end{array}$ & $\begin{array}{l}17(28.30) \\
22(36.70) \\
21(35.00)\end{array}$ & $\begin{array}{l}39(32.50) \\
41(34.17) \\
40(33.30)\end{array}$ \\
\hline
\end{tabular}

Note: Figures in parentheses indicate percentages 
Impact of Abuse Potential of Alcoholic and Non- alcoholic Fathers on Adjustment Pattern of Rural Adolescents

Table 2: Prevalence of abuse potential among alcoholic and non-alcoholic fathers of the adolescents $(n=120)$

\begin{tabular}{|l|c|c|c|}
\hline $\begin{array}{l}\text { Abuse potential / Score } \\
\text { range }\end{array}$ & $\begin{array}{c}\text { Alcoholic fathers } \\
(\mathbf{n = 6 0 )}\end{array}$ & $\begin{array}{c}\text { Non-alcoholic fathers } \\
(\mathbf{n = 6 0 )}\end{array}$ & $\begin{array}{c}\boldsymbol{\chi} \mathbf{2} \\
\text { Value }\end{array}$ \\
\hline No abuse $(<9.1)$ & $\begin{array}{c}12 \\
(20.00)\end{array}$ & $\begin{array}{c}5 \\
(8.33)\end{array}$ & \\
\cline { 1 - 3 } Low abuse (9.1-17.0) & $\begin{array}{c}34 \\
(56.67)\end{array}$ & $\begin{array}{c}48 \\
(80.00)\end{array}$ & \\
\cline { 1 - 3 } $\begin{array}{l}\text { High abuse (17.1-24.9 and } \\
\text { above) }\end{array}$ & $\begin{array}{c}14 \\
(23.33)\end{array}$ & $\begin{array}{c}7 \\
(11.67)\end{array}$ & \\
\hline
\end{tabular}

Note : Figures in parentheses indicate percentages

** $\mathrm{P}<0.05$

Table 3: Mean scores for punishment experienced by abused adolescents by their alcoholic and non-alcoholic fathers $(n=103)$

\begin{tabular}{|c|c|c|c|c|c|c|c|}
\hline \multirow{3}{*}{$\begin{array}{l}\text { Type of } \\
\text { punishment }\end{array}$} & \multicolumn{2}{|c|}{ Alcoholic Fathers } & \multicolumn{2}{|c|}{ Non-Alcoholic Fathers } & \multicolumn{2}{|c|}{ Total } & \multirow{3}{*}{ t-value } \\
\hline & $\begin{array}{c}\text { Low } \\
\text { abuse } \\
(n=34)\end{array}$ & $\begin{array}{c}\text { High } \\
\text { abuse } \\
(n=14)\end{array}$ & $\begin{array}{c}\text { Low } \\
\text { abuse } \\
(n=48)\end{array}$ & $\begin{array}{l}\text { High } \\
\text { abuse } \\
(n=7)\end{array}$ & $\begin{array}{c}\text { Alcoholic } \\
\text { fathers } \\
(n=48)\end{array}$ & $\begin{array}{c}\text { Non- } \\
\text { alcoholic } \\
\text { fathers } \\
(n=55)\end{array}$ & \\
\hline & Mean \pm SD & Mean \pm SD & Mean \pm SD & Mean \pm SD & Mean \pm SD & Mean \pm SD & \\
\hline Scolding/ shouting & $16.97 \pm 7.09$ & $21.32 \pm 6.28$ & $12.02 \pm 7.03$ & $14.06 \pm 6.27$ & $18.24 \pm 3.19$ & $12.28 \pm 2.57$ & $10.50 *$ \\
\hline $\begin{array}{l}\text { Twisting and } \\
\text { pinching ears/arms }\end{array}$ & $21.19 \pm 7.54$ & $26.33 \pm 6.72$ & $13.78 \pm 6.21$ & $19.52 \pm 5.34$ & $22.69 \pm 3.67$ & $14.51 \pm 3.18$ & $12.12 *$ \\
\hline $\begin{array}{l}\text { Threatening with } \\
\text { weapon }\end{array}$ & $29.13 \pm 6.45$ & $33.96 \pm 4.49$ & $17.02 \pm 4.84$ & $19.53 \pm 4.61$ & $30.54 \pm 5.16$ & $17.34 \pm 4.28$ & $14.19 *$ \\
\hline Beating & $32.87 \pm 4.63$ & $35.17 \pm 4.41$ & $20.97 \pm 4.52$ & $23.88 \pm 4.35$ & $33.54 \pm 5.37$ & $21.34 \pm 4.41$ & $12.66^{*}$ \\
\hline F-ratio & $10.43^{*}$ & 13.61* & $8.67 *$ & 10.09* & 11.78* & $9.43^{*}$ & \\
\hline
\end{tabular}

$* \mathrm{P}<0.01$ 
Impact of Abuse Potential of Alcoholic and Non- alcoholic Fathers on Adjustment Pattern of Rural Adolescents

Table 4: Mean scores on different areas of adjustment of adolescents of alcoholic and nonalcoholic fathers $(n=103)$

\begin{tabular}{|c|c|c|c|c|c|c|c|}
\hline \multirow{3}{*}{$\begin{array}{c}\text { Adjustment } \\
\text { pattern }\end{array}$} & \multicolumn{2}{|c|}{ Alcoholic fathers } & \multicolumn{2}{|c|}{ Non-alcoholic fathers } & \multicolumn{2}{|c|}{ Total } & \multirow{3}{*}{$\begin{array}{c}\text { t- } \\
\text { value }\end{array}$} \\
\hline & $\begin{array}{c}\text { Low abuse } \\
(n=34)\end{array}$ & $\begin{array}{c}\text { High } \\
\text { abuse } \\
(n=14)\end{array}$ & $\begin{array}{c}\text { Low } \\
\text { abuse } \\
(n=48)\end{array}$ & $\begin{array}{c}\text { High } \\
\text { abuse } \\
(n=7)\end{array}$ & $\begin{array}{c}\text { Alcoholic } \\
\text { fathers } \\
(n=48)\end{array}$ & $\begin{array}{c}\text { Non- } \\
\text { alcoholic } \\
\text { fathers } \\
(n=55)\end{array}$ & \\
\hline & Mean \pm SD & Mean \pm SD & Mean \pm SD & Mean \pm SD & Mean \pm SD & Mean \pm SD & \\
\hline $\begin{array}{l}\text { Home } \\
\text { adjustment }\end{array}$ & $64.71 \pm 5.33$ & $60.15 \pm 5.67$ & $76.10 \pm 6.14$ & $72.46 \pm 5.89$ & $71.76 \pm 5.99$ & $75.32 \pm 6.01$ & $2.76^{*}$ \\
\hline $\begin{array}{l}\text { School } \\
\text { adjustment }\end{array}$ & $33.12 \pm 2.13$ & $29.30 \pm 2.01$ & $43.66 \pm 3.99$ & $41.07 \pm 3.13$ & $36.55 \pm 2.45$ & $41.34 \pm 3.33$ & $2.97 *$ \\
\hline $\begin{array}{l}\text { Social } \\
\text { adjustment }\end{array}$ & $45.27 \pm 4.01$ & $40.11 \pm 2.21$ & $38.49 \pm 2.87$ & $36.01 \pm 2.99$ & $35.89 \pm 3.79$ & $39.66 \pm 2.57$ & $4.02 *$ \\
\hline $\begin{array}{l}\text { Health } \\
\text { adjustment }\end{array}$ & $38.06 \pm 2.74$ & $30.54 \pm 1.07$ & $30.95 \pm 2.16$ & $27.55 \pm 1.78$ & $28.75 \pm 1.99$ & $31.02 \pm 2.38$ & $2.48 *$ \\
\hline
\end{tabular}

$* \mathrm{P}<0.01$

How to cite this article: C Mahajan, S Kaur (2016), Impact of Abuse Potential of Alcoholic and Non- alcoholic Fathers on Adjustment Pattern of Rural Adolescents, International Journal of Indian Psychology, Volume 3, Issue 4, No. 66, ISSN 2348-5396 (e), ISSN: 2349-3429 (p), DIP:18.01.159/20160304, ISBN: 978-1-365-39396-9 